\title{
Financial Risk Hedging Instruments for Public Work Contracts
}

\author{
Jana Korytárová \\ Brno University of \\ Technology, Faculty \\ of Civil Engineering \\ korytarova.j@fce.vutbr.cz
}

Michal Špiroch

Brno University of

Technology, Faculty

of Civil Engineering

spiroch.m@fce.vutbr.cz

\author{
Jan Štaffa \\ Brno University of \\ Technology, Faculty \\ of Civil Engineering \\ staffa@post.cz
}

\author{
Petra Papežíková \\ Brno University of \\ Technology, Faculty \\ of Civil Engineering \\ papezikova.p@fce.vutbr.cz
}

DOI 10.5592/otmcj.2015.3.2 Research paper

\section{Keywords}

Public works contracts; Hedging instruments; Estimated value; Tender price; Contract price
PUBLIC WORK CONTRACTS CREATE A SUBSTANTIAL SHARE OF BUILDING INDUSTRY PERFORMANCE AND CONSUME A LARGE AMOUNT OF PUBLIC FINANCIAL RESOURCES. Construction process should be efficient without additional costs and overrun time schedules. A very important point in this process is represented by hedging public contracts against potential risk. There are many instruments used in the Czech Republic - insurance construction contracts, contractual penalty and retention or a bank guarantee to name several of them. But not all of them are as effective as the contractors need them to be. The main aim of this paper is to find an effective set of hedging instruments in contracts for work to sufficiently fulfil their function and protect the goals of both the investor and the contractor impending business risks. Information on hedging instruments has been studied on the sample of 246 public works contracts of sewage facilities and equipment. The empirical part of the research focuses on the extent of hedging instruments used, and discusses their application in the context of efficiency. Research finds out that the most commonly used instruments are retention and bank guarantees. Furthermore, the reasons for significant changes in shares of these instruments in the course of monitoring have been analyzed. The final outputs can have societal benefits and serve the contracting authorities and suppliers as a comparison of conditions of their own work contracts or as a help in creation of new work contracts. As additional outputs of this research is also comparison of contract prices and estimated values of tender according to number of tenders and type of award procedures. 


\section{INTRODUCTION}

The construction sector is traditionally one of the most fundamental ones and forms a significant part of the country's Gross Domestic Product (GDP). In the Czech Republic public work contracts represent approximately $53 \%$ of the total financial volume of all construction production. The projects implementation's is based on legislation. In the Czech Republic it is the Act No. 137/2006, Collection of Laws, on Public Contracts, which specifies precisely the method to be used for selecting the most suitable supplier of the construction, particularly with respect to $3 \mathrm{E}$ (economy, efficiency and effectiveness). It is evident that separate stages of the life cycle of the construction project entail a number of risk factors, which can seriously change or reduce project effectiveness. Against these risk factors that can result in additional costs of the construction or in exceeding construction time schedules, instruments reducing, eliminating or transferring impacts of the above risks on a third party, can be found. The discussion has been carried out about a range of hedging instruments aiming at reducing business risk.

The aim of the authors of this paper is to find out what hedging instruments are currently employed, at what values and if the instruments fulfil the functions required. The authors worked with a long-time data collection between April 2012 and August 2014. During this period found a set of 246 specific public work contracts for building sewage treatment plants and the appropriate sewage systems with financial volume in total 342,895,412 EUR ${ }^{1}$. The average value of one contract was $1,393,884$ EUR. Median showed that the number of lower value contracts was greater

Average rate of exchange in the years 2013 and 2014 was $26.75 \mathrm{Kč} / €$ than the average calculation, namely 904,361 EUR. On average, 7 tenders were submitted for each contract and the average time for implementation of the work was about 381 days. There were particularly insurance, contractual penalties, retention and bank guarantees that were found among the examined instruments in the set of contracts studied.

\section{Methodology}

The first step of creating the database consisted in listing the profile addresses of investors occurring in specific contracts and, subsequently, looking up the published contract for work. With respect to such a long-time data collection generating a great number of data, immediately at the start it, was proceeded to selection of public contracts covering projects related to construction of sewage treatment plants and the appropriate sewage systems (STP), primarily for the following reasons:

a great number of public contracts which are uniform with respect to the branch,

significant municipal contracts with a higher price and importance for risks hedging,

$\checkmark$ various investors and contractors over the entire Czech Republic.

Consequently, all the findings presented in the article are based on analysis of the data recorded, collected and sorted over a long time period. Thus a relatively unique database of contracts for work was created, which - thanks to its extensiveness - offers a comprehensive and trustworthy view of the use of hedging instruments in public contracts in the Czech Republic. At the same time, thanks to its potential, the database exceeds mere concentration on hedging instruments, thus being able to place the data also in a wider context. Final output can have societal benefits and serve contracting authorities (particularly municipalities), including suppliers, e.g. for comparison with the conditions of their own work contracts to show them if the contracts are not disadvantageous for them, or if they do not exceed the established practice. Simultaneously, it can contribute to a more effective selection of hedging instruments if a contract for work is just being created. The research data has provided also other interesting characteristic of public work contracts in comparison of contract prices and estimated values of tender.

\section{Results and discussion}

The first part of the research deals with hedging instruments. Based on the analysis above mention of sample it can be said that the most frequently used hedging instruments for public construction works contracts in the Czech Republic are:

1. property insurance and insurance of liability for damages,

2. contractual penalty,

3. retention and

4. bank guarantee.

Insurance ranks among important hedging instruments in construction projects (FIDIC). Insurance is often the cheapest method (when available) for managing catastrophic-type physical risks and for managing higher levels of liability exposures (Edwards, 1995). It is particularly the insurance of liability for damages and constructionassembly insurance that appear in contracts for work. The insurance of liability for damages were found in $85 \%$ of the sample examined and was more frequent than the property insurance, which was arranged in $65 \%$ of the sample examined. However, the lower than expected numbers can be due to the fact that prior to imposition of the Act No. 55/2012, Collection of Laws, (3), the requirement to arrange the insurance could be included in qualifications prerequisites within the competitive tender (selection procedure). The tenderer who passed the qualifications procedure had concluded the required 
insurance and consequently it was not necessary to include this in contracts. Since the source database was being created from the start of the validity of the act amendment (1st April 2012) it is certain that some contracts were already in the process of placement of orders and insurance of the first contracts given in the database was still a part of the qualifications. The authors of the present paper believe that in case of the liability insurance, the realistic number would exceed $90 \%$ of the frequency occurrence.

In case of the construction-assembly insurance, price of the work after its completion can be considered as an effective value of the sum insured, which holds also for property damage liability insurance where, however, also a smaller sum insured can be tolerated. On the contrary, an over insurance can cause higher financial insurance costs for the contractor, usually in orders of tens of thousands, which they subsequently, include in the tender price of all tenderers. However, it is appropriate to say that in case of contracts at the value of several tens of thousands Euro, a more effective selection of the sum insured can bring only small savings in order of tenths of percent of the total price of work.

Contractual penalty is the most frequently used business risk hedging instrument. It is comprehensible, administratively undemanding and has an appreciated preventive effect. In the analyzed database, contractual penalties occurring most frequently in 243 contracts for work were as following: contractor's delay in the construction completion date, exceeding deadline for elimination of defects and arrears of work, investor's delay in payment invoices (invoices exceeding their due dates), failure in keeping the term of clearing the construction site and failure in keeping the term of the start of defects elimination.

Retention belongs to traditional forms of business risks hedging in con- tracts for work. It is a common practice in the construction industry to withhold a small proportion of payments to a contractor until the work has been completed satisfactorily (Hughes \& al, 2009). Its usual size in the Czech construction practice is $10 \%$ of the price of work and usually is paid after expiration of the guarantee period. It might be interesting that for instance the amount California public entities retain from public works contract payments ranges from $10 \%$ to $5 \%$, in most cases (Atkinson \& al, 2011). Under the new law, the retention withheld cannot exceed $5 \%$ of the payment, and in any case shall the total retention proceeds withheld exceed $5 \%$ of the contract price (Jones Day, 2012).

Occurrence of retention in contracts for work was found in 107 cases out of 246 contracts monitored. An analysis of the contracts with regards to the use of this instrument provided interesting results when followed on a time axis. Till 2013, the occurrence frequency was 59 out of 100 , since 2014 the frequency has decreased to 44 out of 146 contracts.

The completed analysis indicated that the use of retention in contracts for work started to decline. Apparently, the main reason for it can be attributed to an extending offer of bank guarantees and their more frequent use in contracts for work. Thanks to their nature, bank guarantees provide the investor a similar security as retention while offering the contractor (supplier) numerous advantages.

By its function in the contract of work, bank guarantee is close to the financial retention sum (retention). As the most significant advantage of a bank guarantee compared to retention, can be considered its ability to guarantee financial means to the investor in case of the failure of the contractor to keep the terms of the agreement without the necessity to retain or otherwise freeze contractor's money. Very often are especially performance guaran- tee, warranty guarantee and retention guarantee. The essential difference between the above bank guarantees consists in the fact that the first two guarantees are characterized by the obligation to submit them to the investor while the retention guarantee was incorporated into contracts rather as a possibility of a compensation for the financial retention.

Similarly as in case of retention, the time axis for the value of frequency of their use is of interest. The Performance Guarantee occurred in the contracts for work before 31 December 2013 in only 33\%, the Warranty Guarantee even only in 30\% of contracts. Since 1 January 2014 the relation has changed significantly. The Performance Guarantee was recorded in $70 \%$ of contracts and the Warranty Guarantee in $73 \%$ of contracts. The changes of these hedging instruments (retention and bank guarantees) in time are shown in the Figure 1 below.

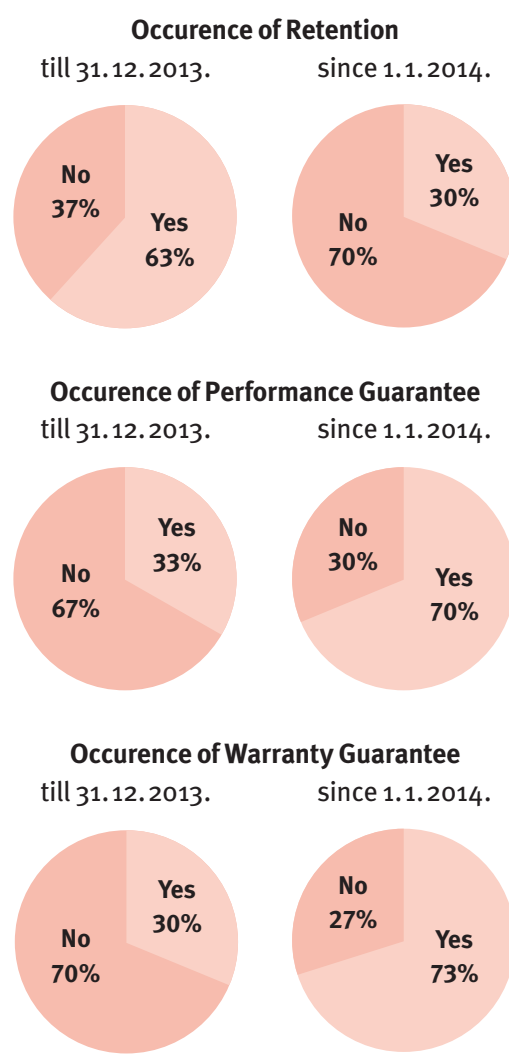

Figure 1: Changes in Using Retention and Bank Guarantees in time 


\begin{tabular}{|c|c|c|c|c|}
\hline \multicolumn{2}{|c|}{ Hedging Instruments } & \multicolumn{2}{|c|}{ Amount } & Price limit \\
\hline \multirow{2}{*}{ Insurance } & liability for damage & $80-100 \%$ & of price of work & $\begin{array}{l}24 \text { mil. }-30 \text { mil. CZK } \\
(0.9-1.12 \mathrm{mil} €)\end{array}$ \\
\hline & property & $100 \%$ & of price of work & 30 mil. CZK (1.12 mil €) \\
\hline \multirow{5}{*}{ Contractual Penalty } & $\begin{array}{l}\text { contractor's delay } \\
\text { in thecontstruction } \\
\text { completion date }\end{array}$ & $0,10 \%$ & of price of work & \multirow{5}{*}{$\begin{array}{l}\text { total limit of payments } \\
\text { of contractual penalties } \\
20 \% \text { price of work } \\
\text { (till } 6 \text { mil. CZK, } \\
0.22 \text { mil. } € \text { ) }\end{array}$} \\
\hline & $\begin{array}{l}\text { exceeding deadline for } \\
\text { elimination of defects and } \\
\text { arrears of work }\end{array}$ & 5,000 CZK (187 €) & $\begin{array}{l}\text { per damage and every } \\
\text { commenced day }\end{array}$ & \\
\hline & $\begin{array}{l}\text { investor's delay in } \\
\text { payment invoices }\end{array}$ & $0,10 \%$ & of outstanding amount & \\
\hline & $\begin{array}{l}\text { faliure in keeping the } \\
\text { term of clearing the } \\
\text { construction site }\end{array}$ & 5,000 CZK (187 €) & per every commenced day & \\
\hline & others & \multicolumn{2}{|c|}{ to select others useful penalty } & \\
\hline \multicolumn{2}{|c|}{ Retention } & \multicolumn{3}{|c|}{ not to apply } \\
\hline \multirow{3}{*}{ Bank guarantee } & Performance guarantee & \multicolumn{3}{|c|}{ not to apply } \\
\hline & Warranty guarantee & $10 \%$ & of price of work & 3 mil. CZK (0.11 mil €) \\
\hline & Retention guarantee & $5 \%$ & of price of work & 1.5 mil. CZK (0.06 mil €) \\
\hline
\end{tabular}

Figure 2: Recommendation for standard work contract in the Czech Republic

From the above listed facts, a recommendation has been drawn for a standard construction work contract. For every contract a mix of hedging instruments should be created comprising a) insurance b) contractual penalties and c) performance bank guarantees. This recommendation raised by this research for a standard construction work contract in the Czech Republic is shown in the Figure 2.

The research data has provided also other interesting characteristic of public work contracts. Important part of these public contracts is a work contract limited lifetime warranty. Construction works usually have warranty of 60 months. The total sample of 245 contracts (one contract value was not found) confirmed it, the five-year warranty period occurred in nearly $85 \%$, which it is shown in the Figure 3 .
The final outputs deal with comparison difference between contract price (in contract for work) and estimated value of tender according to type of award procedure and number of received tenders. Public contracts in research database were performed in two types of award procedures: open and restricted procedure (224 public contracts were analysed). Figure 4 illustrates this comparison in \%.

The next question was, if any differ-

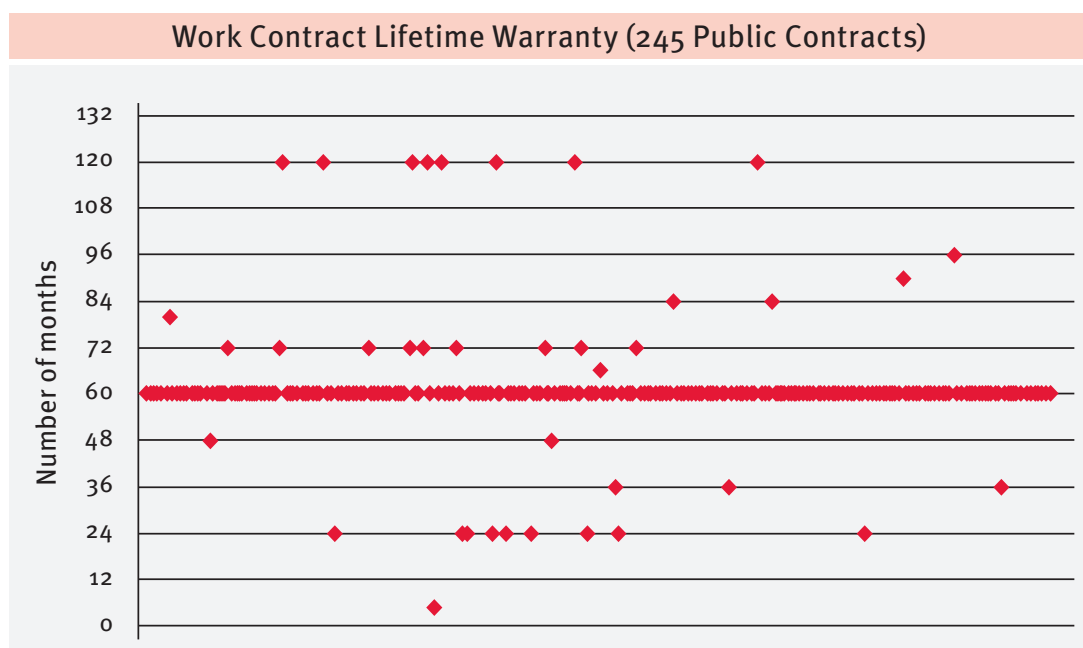

Figure 3: Lifetime of Warranty 

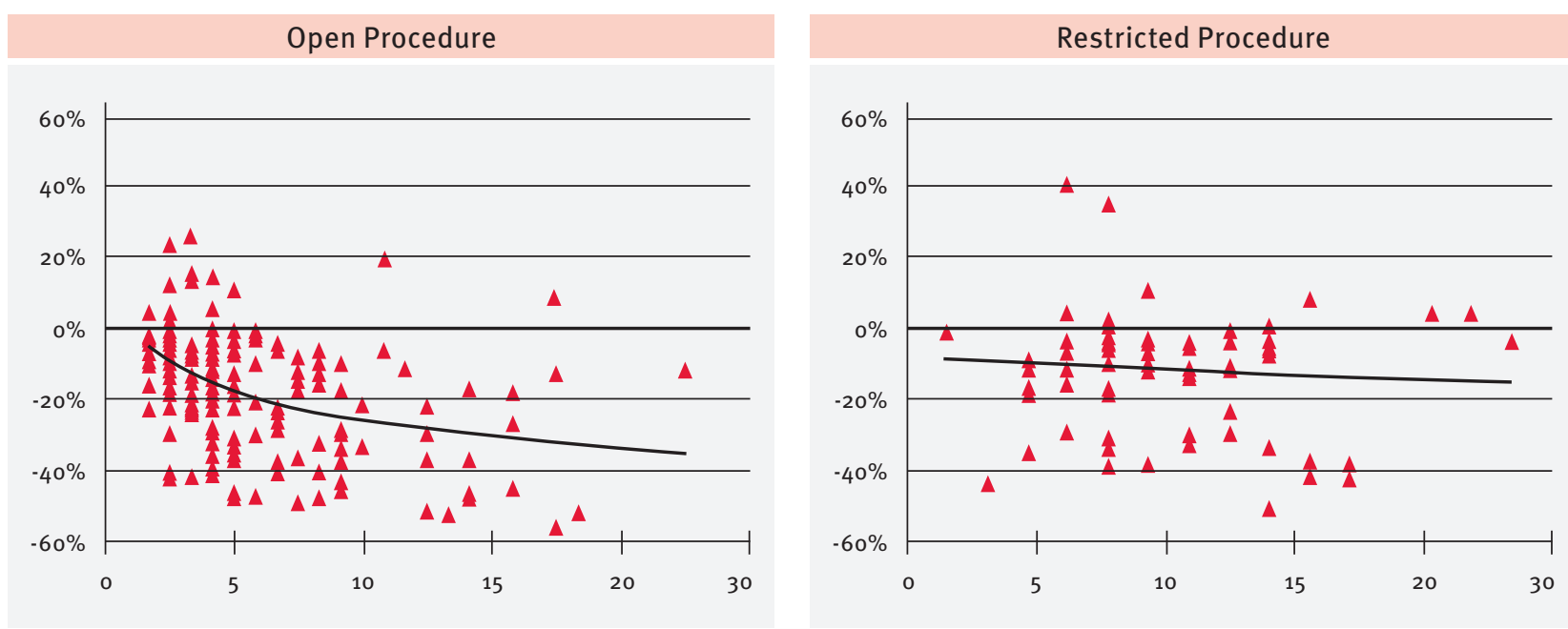

Figure 4: Comparison of Contract Price and Estimated Value in two types of Award Procedures

ence can affect the number of tenders or types of award procedure. The comparison of trend curve is shown in the Figure 5 .

When interpreting the Figure 5 , it is to be noted, that both sets of data did not contain the same number of tenders and showed considerable variance in processing values (see Figure 4). Therefore the regression equations of lines have a very low degree of reliability. It is necessary to regarded only as an illustration of the trend. Nevertheless this analysis on a relatively large sample of data shows the downtrend of both straight lines and optically visible differences between these two types of award procedures. It is thus concluded, although generally, but likely conclusion that:

$\checkmark$ increased number of tenders received contribution to a lower price of the work

$\checkmark$ open procedure has greater potential to achieve lower price and adopt a larger number of tenders.

\section{Conclusion}

This paper focuses on the analysis of use of hedging instruments employed in public construction contracts and on assessment of a reasonable extent of their use in contracts for work. Analysis was carried out on an extensive sample of 246 contracts for work con- cluded from public orders for construction of waste-water treatment plants and the related sewage systems. Major concern has been to determine how the hedging instruments are used and how their amount is set up.

Based on the analysis of the sample examined, it is apparent that the Czech building practice uses most frequently property and damage liability insurance, contractual penalties, retention and bank guarantees. The research has revealed that the frequency of use of the separate instruments has been changing recently. The da- tabase was being created between April 2012 and August 2014, i. e. at the time when the Czech Public Contracts Act was amended. In 2012, the amendment left out from the Act the investor's requirement to request the contractor to prove his financial and economic qualifications prerequisites. Insurance is one of the instruments examined, which does not appear in contracts for work concluded prior to coming of the above act amendment into force, probably due to the fact that it is a part of qualifications prerequisites. A recommendation raised

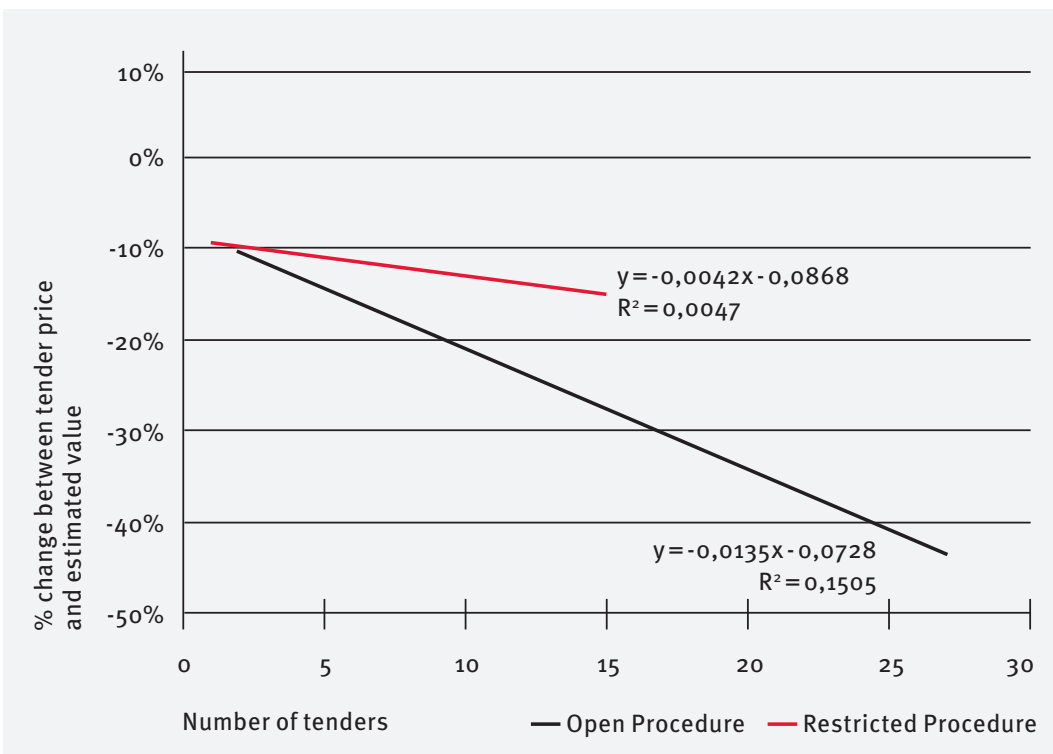

Figure 5: Change between Contract Price and Estimated Value according to numbers of Tenders and Type of Award Procedures 
by this research for a standard construction work contract is a mixture of hedging instruments comprising selected types of insurance, contractual penalties and bank guarantees.

Finally, it is apparent that the type of award procedure has an effect on the number of submitted tenders and also on the tender price.

\section{Acknowledgement}

This paper has been worked out under the project No. LO1408 "AdMaS UP - Advanced Materials, Structures and Technologies", supported by Ministry of Education, Youth and Sports under the „National Sustainability Programme I" and supported by project no. FAST-S-14-2488 Effective management processes in the building industry, Brno University of Technology.

\section{References}

Act No. 137/2006 Coll., on Public Contract as Amended Act. No. 55/2012 Coll., Czech Republic

FIDIC, CONS (Red Book), Conditions of Contract for Construction For Building and Engineering Works Designed by the Employer, First Edition 1999, International Federation of Consulting Engineering

Korytárová, J. et al., 2011. Management rizik souvisejících s dodávkou stavebního díla (Management of risks associated with the delivery of construction work), Akademické nakladatelství CERM, Brno, 147 p. ISBN 97880-7204-725-3.

Štaffa, J., 2015Formy jištění obchodního rizika stavebního díla (Forms of Business Risk Protection of Construction work).110 p. Diplomová práce (Masters thesis), Brno University of Technology, Faculty of Civil Engineering. Brno. Supervisor assoc. prof. Jana Korytárová, MSc., Ph.D.
Hudges, W., Champion, R., Mudroch, J., 2008. Construction contracts: law and management. Taylor \& Francis, Oxon OX14 4RN. p. 219

Edwards, L., 1995. Practical risk management in the construction industry. Thomas Telford, London 1995. ISBN o 727720643

Atkinson, Andelson, Loya, Ruud \& Romo, 2011. A Professional Law Corporation, A New Law Limits Retention to $5 \%$ on Public Works Projects.

Jones Day, 2012.California Construction Law: Important Changes Ahead. USA 